\title{
The Perceived Quality of Store Brands: The Effect of Price Promotion and Quality Guarantees
}

\author{
Sultan Alenazi ${ }^{1}$, Mohamed Almotairi ${ }^{1} \&$ Soad Al-Meshal ${ }^{1}$ \\ ${ }^{1}$ College of Business Administration, King Saud University, Riyadh, Saudi Arabia \\ Correspondence: Sultan Alenazi, Assistant Professor, Department of Marketing, College of Business \\ Administration, King Saud University, Riyadh, Saudi Arabia. E-mail: alenazis@yahoo.com
}

Received: May 25, 2015 Accepted: June 20, 2015 Online Published: July 30, 2015

doi:10.5539/ijms.v7n4p88 URL: http://dx.doi.org/10.5539/ijms.v7n4p88

\begin{abstract}
This research examines the effect of price promotion on the quality of store brands and national brands. It also examines the effect of a quality guarantee on the perceived quality of store brands. These findings suggest that store brands, but not national brands, are negatively affected by price promotion. However, a quality guarantee can counterbalance the negative effect of price promotion. Finally, the research results show that purchase intention is positively affected by perceived quality.
\end{abstract}

Keywords: product quality perception, price promotion, store brand quality guarantee

\section{Introduction}

Store brands, also known as private labels, have been major players in the retail market. With a market share of $24 \%$ of U.S. supermarkets (Marketing Daily, April $6^{\text {th }}, 2010$ ), store brands continue to win consumer choice. Retailers offer their own brands either to increase their profits or gain greater customer loyalty. Consumers today continue to adopt store brands in many product categories, such as fresh and canned foods, cleaning products, and pain relief products. Retailers often offer the same products as national brands, but at lower prices. Lowering the cost of packaging and advertising allows retailers to lower the prices of their own brands (Cunningham, Hardy, \& Imperia, 1982). Although store brands have been studied to a great extent in the current literature, the effect of promotion on store brand quality has not received as much attention. Since product quality is important for the success of store brands (Erdem et al., 2004; Choi \& Coughlan, 2006; Wulf, 2005), understanding the effect of different marketing practices on the perceived quality of store brands needs to be further considered.

Among those practices are promotional decisions taken by managers to increase sales. Since price promotion is common for sellers of store brands, it is important to investigate the effect of such a practice on consumer behavior. Although retailers do compete by positioning their products at different levels of perceived quality, understanding the effect of promotion on the perceived quality of store brands is also important. Lowering product perceived quality can be a negative effect of different types of promotions (Dodson, Tybout, \& Sternthal, 1978; Doob et al., 1969). Indeed, the current literature offers no research on the direct examination of the effect of price promotion on the perceived quality of store brands.

This study aims to fill this gap by examining the effect of product type, national vs. store brand, on the relationship between price promotion and perceived quality. It also examines how a quality guarantee may moderate the effect of that promotion on store brand perceived quality. We argue that promotion has a negative effect on perceived quality in the case of store brands, but not in the case of national brands. Consumers tend to have a greater concern about the quality of store brands than they do about national brands. In addition, we expect quality guarantees to lessen the effect of the promotion on the perceived quality of store brands.

Current research has implications for both theory and practice. Theoretically, this research adds to our understanding of the differences between store brands and national brands in terms of the effects of promotion on perceived quality and also sheds further light on the benefits of offering a quality guarantee on their store brands in terms of consumer perception of the actual quality of store brands. Understanding the effect of price promotion and quality guarantee on consumer perception of quality is important for retailers, as they attempt to win the choices of their consumers. 


\section{Theoretical Background}

\subsection{Effect of Promotion on Perceived Quality}

Promotions are used by managers to enhance sales. However, promotions are not without certain negative consequences. Lower perceived quality is one of the negative consequences of promotions. The marketing literature, however, offers inconsistent evidence to support such an effect. For example, Doob et al. (1969) found promotion to have a negative effect on brand evaluation. In their five experiments on the effect of promotion on household products, Doob et al. (1969) found that subsequent sales were higher when the initial price was high than when it was low, i.e., a low introductory price. They explained this finding using the dissonance theory. When consumers pay more for a brand, they will like it more. This higher appreciation based on price is also reflected in a higher repurchase probability. A similar finding was reported by Dodson, Tybout, \& Sternthal (1978), who found promotion to have a negative effect on repurchase probability. This decrease in repurchase probability was seen as the result of decreased consumer brand evaluation. Munger and Grewal (2001) also found promotion to have a negative effect on perceived quality.

However, the negative effect of promotion on brand evaluation has also been challenged by other researchers (Neslin \& Shoemaker, 1989; Davis, Inamn, \& McAslister, 1992). In a direct measurement of brand evaluation, Davis, Inamn, and McAslister (1992) found that promotion not only failed to have a negative effect, but also positively affected brand evaluation. Grewal et al. (1998) found that any negative effect of a price discount on perceived quality was counterbalanced by the positive effect of the brand's name. They concluded that any negative effect of price promotion disappears if the brand is known to be of high quality. Other researchers argued that the negative effect of price promotion can happen only under certain circumstances. For example, Raghubir and Corfman (1999) found that price promotion has a negative effect on perceived quality only when such promotion deviates from either past promotional behavior of the firm or from the promotional norm of the industry. Raghubir (2004) found that coupons positively affect perceived quality when they infer a higher price. Specifically, when coupons infer a product to be high priced, perceived quality is positively affected and such effect happens when other product price information is absent or when prices of other products vary significantly.

\subsection{Store Brand vs. National Brand}

Although they have been growing as major competitors for national brands, store brands have not as yet experienced much research to explain consumers' perception of those brands (Cataluna, 2006; Richardson, 1997; Wulf et al., 2005). Store brand literature has not focused on how promotion might affect the perceived quality of store brands. Store brands are generally perceived by most customers to be of a lower quality than national brands (Mieres et al., 2006). Bellizzi et al. (1981) found that national brand were perceived as superior to private brands in many aspects, including reliability and quality. A similar result was reported by Richardson, Dick and Jain (1994).

In their study of store brand perception in an emerging market in Turkey, Dolekoglu et al. (2008) found store brands to be of a lower quality than national brands. A similar finding was reported by Bhukya and Singh (2013). In their study of consumers' attitudes toward private labels in India, Bhukya and Singh (2013) found that consumers perceived private labels to be cheap and of a lower quality. However, perceived quality remains an important factor for the success of any brand, including store brands. Erdem et al. (2004) argued that quality is more important than low price in terms of the success of store brands. Therefore, retailers need to learn how to improve the perception of their stores brands in terms of their quality. Because national brands are perceived to be of a higher quality than store brands, we expect promotion to have a negative effect on store brands, but not on national brands. Indeed, the negative effect of price promotion on perceived quality was found not to hold when that brand was already known to be of high quality (Grewal et al., 1998). Based on all the literature, reviewed here, we developed the flowing hypothesis:

H1: A two-way interaction exists between price promotion and brand type that will affect perceived qyality, such that price promotion will have a negative effect on store brands, but not on national brands.

\subsection{Quality Guarantee}

A quality or money back guarantee is a promise by the seller to refund the money to the buyer if the purchased product is not of the expected quality. Today, quality guarantees can be found for many categories of products, ranging from expensive durables to less expensive products, such as a can of green beans. When faced with price promotions, consumers might attribute that promotion to specific factors, such as competition or an issue with product quality. If consumers attribute the promotion to a problem with product quality, then perceived quality 
will be lower. One way of overcoming this problem is to provide consumers with an explicit guarantee of product quality (DelVecchio et al., 2006). Marketers soon started to recognize the importance of such a quality guarantee. However, no empirical study has yet examined the effect of such a guarantee on store brand perceived quality. Based on the literature reviewed above, we developed the following hypothesis:

H2: A two-way interaction between price promotion and quality guarantee will affect store brand perceived quality, such that a quality guarantee will have a positive effect on store brand perceived quality when a brand is promoted, but not when a brand is not promoted.

In terms of purchase intention, perceived quality has been found to affect purchase intention positively. In a similar way we offer the following hypothesis:

H3: Perceived quality will have a positive effect on purchase intention.

\section{Study 1}

\subsection{Participants and Procedure}

Study 1 tested the hypothesis for the interaction effect of price promotion and brand type on perceived quality. One hundred and sixty nine students participated in a 2 brand (Brand: national brand and store brand) X 2 (price discount: presence and absence) between subjects experiment. Subjects were randomly assigned to one of the experimental conditions and then asked to review the following scenario:

While coming back from school, you stopped by a nearby grocery store to buy a frozen pizza for dinner. For the national brand condition, subjects read "you found a national brand pizza of your choice" while for the store brand condition, subjects read "you found a store brand pizza of your choice". In the price discount condition only, subjects read that "a $30 \%$ discount was offered on the chosen pizza".

After reading the scenario, the subjects were asked to respond to the following dependent measures and manipulation checks.

\subsection{Dependent Measures}

Perceived quality was measured using a 3- item, 7-point Likert scale. The first two items were adjusted from Purohit and Srivastava (2001) and the last item was adjusted from Jang and Young (2009). "This pizza should be of (very poor to very high quality)"; "My overall impressions of the pizza are (very bad to very good)"; "The pizza is most likely going to be tasty" (strongly disagree to strongly agree). Purchase intention was measured by the subjects' responses to a question asking about their likelihood of buying the pizza (definitely will not buy to definitely will buy).

\subsection{Manipulation Check}

All student participants except for six answered the questions about brand type and price promotion correctly. The data of those six subjects were thus excluded from the subsequent analysis.

\subsection{Results}

A two-way ANOVA revealed that the interaction between brand type and price promotion had a significant effect on perceived quality $(\mathrm{F}(1,159)=4.11, \mathrm{P}<.05)$. Table 1 provides the means and standard deviations of the perceived quality. In the store brand condition, perceived quality was lower when a price discount was offered than when it was not offered $(\mathrm{M}$ discount $=3.68$, $\mathrm{M}$ no discount $=4.18, \mathrm{~F}(1,159)=8.77, \mathrm{P}<.004)$. However, in the national brand condition, perceived quality was not different for the price discount and no price discount conditions, $(\mathrm{M}$ promotion $=4.60, \mathrm{M}$ no promotion $=4.64, \mathrm{~F}(1,159)<1, \mathrm{P}$ ns). This results support $\mathrm{H} 1$. In terms of $\mathrm{H} 3$, which suggested that perceived quality would positively affect purchase intention, a regression analysis showed that perceived quality had a positive effect on purchase intention $(\boldsymbol{b}=.179, \mathrm{t}=2.52, \mathrm{P}<.05)$.

Table 1 . Study 1 cell means and standard deviations

\begin{tabular}{llll}
\hline & & \multicolumn{2}{c}{ Brand Type } \\
\hline Promotion & Yes & National & Store \\
& No & $4.60(1.2)$ & $3.68(1.18)$ \\
& $4.64(.97)$ & $4.18(1.02)$ \\
\hline
\end{tabular}

Note. Standard deviations are in parentheses. 


\subsection{Discussion}

The results of Study 1 support the expected effect of price promotion on perceived quality. We found price promotion to have a negative effect on perceived quality of store brands, but not national brands. This result can be explained by the superiority of national brands to store brands. Consumers might attribute the price promotion of national brands to other reasons than a problem with product quality. This finding also supports some of the previous research as discussed earlier. On the other hand, store brand price promotion might be attributed by consumers to an issue with the product quality. In addition, perceived quality was found to affect purchase intention positively. To overcome such a negative effect of price promotion on store brands, Study 2 was conducted to test the effect of a quality guarantee on a price promoted store brand.

\section{Study 2}

\subsection{Participants and Procedure}

Study 2 tested the hypothesis for the interaction effect of price promotion and quality guarantee on perceived quality. Two hundred and fifty three students participated in this study. The study utilized a 2 (price discount: presence and absence) X 2 (quality guarantee: presence and absence) between the subjects as its design. Subjects were randomly assigned to one of the experimental conditions and then asked to read the following scenario:

While coming back from school, you stopped by a nearby grocery store to buy a frozen pizza for dinner, and you found a store brand pizza of your choice. For the price discount condition only, subjects read "a $30 \%$ discount was offered on the chosen pizza". For the quality guarantee condition only, subjects read that "the store offers a quality guarantee on the chosen pizza".

After reading the scenario, participants were asked to respond to the dependent measures and manipulation checks. The same measurement scales for Study 1 were used in Study 2 to measure both perceived quality and purchase intention.

\subsection{Manipulation Check}

All participants except four answered the questions about the price discount and quality guarantee correctly. The data of those four subjects were thus excluded from the subsequent analysis.

\subsection{Results}

The results of a two-way ANOVA revealed that the interaction between price discount and quality guarantee had a significant effect on perceived quality $(\mathrm{F}(1,245)=5.40, \mathrm{P}<.05)$. Table 2 provides the means and standard deviations of the perceived quality. Consistent with $\mathrm{H} 2$, in the price discount condition, perceived quality was higher when a quality guarantee was offered than when it was not offered ( $\mathrm{M}$ no guarantee $=3.69, \mathrm{M}$ guarantee $=5.23, \mathrm{~F}(1,245)=4.96, \mathrm{P}<.05)$. However, in the no price discount condition, perceived quality was not different for the quality guarantee and no quality guarantee conditions, $(\mathrm{M}$ no guarantee $=4.62, \mathrm{M}$ guarantee $=$ $4.78, \mathrm{~F}(1,245)<1, \mathrm{P} \mathrm{ns})$. In terms of the effect of perceived quality on purchase intention, the results supported $\mathrm{H} 3$, which suggests that perceived quality would positively affect purchase intention. Regression analysis showed that perceived quality had a positive effect on purchase intention $(\mathbf{b}=.188, \mathrm{t}=3.43, \mathrm{P}<.005)$.

Table 2. Study 2 Cell Means and Standard Deviations

\begin{tabular}{llll}
\hline & & \multicolumn{2}{c}{ Promotion } \\
\hline Guarantee & Yes & Yes & No \\
& No & $5.23(1.34)$ & $4.78(1.09)$ \\
& $3.69(1.16)$ & $4.62(1.22)$ \\
\hline
\end{tabular}

Note. Standard deviations are in parentheses.

\subsection{Discussion}

The results for Study 2 supported H2. This hypothesis stated that expected quality guarantee will have a positive effect on perceived quality of price promoted store brands. Specifically, quality guarantee had a positive effect on perceived quality of store brand when the store brand was promoted. In addition, the results offered additional support for $\mathrm{H} 3$, which suggests that perceived quality has a positive effect on purchase intention. 


\section{General Discussion and Managerial Implications}

This research examined the effect of price promotion on a product's perceived quality and purchase intention. The results of Study 1 revealed that price promotion has a negative effect on store brands, but not on national brands, likely due to the perception of the national brand as being of higher quality than the store brand. Study 2, however, demonstrated that this negative effect can be reduced by offering a quality guarantee. In both studies, perceived quality was found to have a positive effect on purchase intention. This research thus adds to the literature in several ways. First, it shows that differences between store brands and national brands do moderate the effect of price promotion on perceived quality. Second, the study shows how promotion context factors can affect the relationship between promotion and perceived quality. Specifically, it shows how quality guarantees can be used to alter how store brands are perceived when those brands are promoted. For marketers, understanding the effect of promotion on store brand perceived quality is essential in order to enhance the performance of store brands. When a certain type of product is promoted by national manufacturers, stores often find it necessary to promote their own brand of the same product type. As the current research reveals, this practice has a negative effect on store brand perceived quality. One way of overcoming this effect is offering a quality guarantee. Stores might also seek out other means of competing with national brands other than price promotion.

\section{Limitations and Future Research}

First, the participants in this research were students. Future research should be conducted on other types of consumers in order to generalize the current findings further. Second, a discount level may also affect consumers' perception of product quality. Current research examined only one discount level. Future research might examine the same current hypotheses with different levels of discounts. Another good possible avenue of future research would be to examine the current hypotheses using other types of price promotions, such as coupons and free samples.

\section{Acknowledgments}

The authors would like to thank The Research Center of the College of Business Administration, King Saud University for providing support for this research.

\section{References}

Bellizzi, J. A., Kruckeberg, H. F., Hamilton, J. R., \& Martin, W. S. (1981). Consumer perceptions of national, private, and generic brands. Journal of Retailing and Consumer Services, 57(4), 56-70.

Bhukya, R., \& Singh, S. (2013). Consumers' perception towards private label products of Indian retailers-A study on super markets in Hyderabad. International Journal of Business, Management \& Social Sciences, 2(12). http://dx.doi.org/10.2139/ssrn.2508114

Choi, S. C., \& Coughlan, A. T. (2006). Private label positioning: Quality versus feature differentiation from the national brand. Journal of Retailing, 82(2), 79-93.

Cunningham, I. C. M., Hardy, A. P., \& Imperia, G. (1982). Generic brands versus national brands and store brands. Journal of Advertising Research, 22(October/November), 25-32.

Dolekoglu, C. D., Albayrak, M., Kara, A., \& Keskin, K. (2009). Analysis of consumer perceptions and preferences of store brands versus national brands: An exploratory study in an emerging market. Journal of Euromarketing, 17(2), 109-125. http://dx.doi.org/10.1080/10496480802134787

Dodson, J. A., Tybout, A. M., \& Sternthal, B. (1978). Impact of deals and deal retraction on brand switching. Journal of Marketing Research, 15(February), 72-81. http://dx.doi.org/10.2307/3150402

Doob, A. N., Carlsmith, J. M., Freedman, J. L., Landauer, T. K., \& Saleng, Jr. T. (1969). Effects of initial selling price on subsequent sales. Journal of Personality and Social Psychology, 11(4), 345-350. http://dx.doi.org/10.1037/h0027415

Davis, S., Inman, J. J., \& McAlister, L. (1992). Promotion has a negative effect on brand evaluations - Or does it? Additional disconfirming evidence. Journal of Marketing Research, 29(February), 143-148. http://dx.doi.org/10.2307/3172499

Erdem, T., Zhao, Y., \& Valenzuela, A. (2004). Performance of store brands: A cross-country analysis of consumer store brand preferences, perceptions, and risk. Journal of Marketing Research, 41(February), 86-100. http://dx.doi.org/10.1509/jmkr.41.1.86.25087 
Grewal, D., Monroe, K., \& Krishnan, R. (1998). The effects of price comparison advertising on buyers' perceptions of acquisition value, transaction value, and behavioral intentions. Journal of marketing, 62(2), 46-59. http://dx.doi.org/10.2307/1252160

Mieres, C., Martin, A., \& Gutiérrez, J. (2006). Antecedents of the difference in perceived risk between store brands and national brands. European Journal of Marketing; 40, 61-82. http://dx.doi.org/10.1108/03090560610637310

Munger, J. L., \& Grewal, D. (2001). The effects of alternative price promotional methods on consumers' product evaluations and purchase intentions. Journal of Product \& Brand Management, 10(3), 185-197. http://dx.doi.org/10.1108/10610420110395377

Neslin, S. A., \& Shoemaker, R. W. (1989). An alternative explanation for lower repeat rates after promotion purchases. Journal of Marketing Research, 26(May), 205-213. http://dx.doi.org/10.2307/3172606

Raghubir, P., \& Corfman, K. (1999). When do price promotions affect pretrial brand evaluations? Journal of Marketing Research, 36(2), 211-22. http://dx.doi.org/10.2307/3152094

Raghubir, P. (2004). Coupons in context: Discounting prices or decreasing profits? Journal of Retailing, 80, 1-12. http://dx.doi:10.1016/j.jretai.2004.01.001

Richardson, P. (1997). Are store brands perceived to be just another brand? Journal of Product and Brand Management, 6(6), 388-404.

Richardson, P. S., Dick, A. S., \& Jain, A. K. (1994). Extrinsic and intrinsic cue effects on perceptions of store brand quality. Journal of Marketing, 58(October), 28-36. http://dx.doi.org/10.2307/1251914

Wulf, K., Odekerken Schroder, G., Goedertier, F., \& Van Ossell, G., (2005). Consumer perceptions of store brands versus national brands. Journal of Consumer Marketing, 22(4), $223-232$. http://dx.doi.org/10.1108/07363760510605335.

\section{Copyrights}

Copyright for this article is retained by the author(s), with first publication rights granted to the journal.

This is an open-access article distributed under the terms and conditions of the Creative Commons Attribution license (http://creativecommons.org/licenses/by/3.0/). 